\title{
Factors influencing fertiliser and lime decisions on South Island high- and hill-country farms
}

\author{
Xiaomeng K. S. LUCOCK ${ }^{1, *}$ and Jim L. MOIR ${ }^{2}$ \\ ${ }^{1}$ Faculty of Agribusiness and Commerce, ${ }^{2}$ Faculty of Agriculture and Life Sciences, \\ PO Box 85084, Lincoln University, Lincoln 7647, Christchurch, New Zealand \\ *Corresponding author: sharon.lucock@lincoln.ac.nz
}

\section{Highlights}

- Fertiliser and lime decisions by high- and hill-country farmers directly impact on their farm performance, but the factors influencing these decisions are not well understood.

- Factors influencing South Island high- and hillcountry farmers' fertiliser and lime decisions are a complex matrix of both biophysical and socioeconomic components, such as costs, location, soil conditions and public perception.

- Factors influencing these farmers' fertiliser and lime decisions reflect the complex farm systems and the wider socio-economic environment that they operate within. A greater empathy between the farming and non-farming communities will help alleviate some of the challenges faced by these farmers.

Keywords: Fertiliser and lime decisions, high- and hillcountry farmers, regulatory environment, sustainability

\section{Background}

Extensive high- and hill-country farms are key contributors to New Zealand's export income generated from the outputs of multiple primary sectors, particularly sheep, beef, deer, and forestry industries (Ministry of Business Innovation and Employment 2018). For example, sheep meat and beef exports are expected to reach 8.4 billion NZD for the 2019-20 season, which has been steadily trending up since 2014-15 season (Beef + Lamb New Zealand 2019). The location of these high- and hill-country farms are also often regarded as the 'backdrops' of New Zealand, which are increasingly drawing competing interest from tourism in recent years. Adding climate change, tenure review and environmental-protection regulation into the mix, high- and hill-country farmers are faced with pressures from multiple directions while trying to develop and/or maintain the economic viability of their farms and be good stewards of the land.

Fertiliser and lime are a significant proportion of farm expenditure for most New Zealand farms (Moir $\&$ Moot 2014). Extensive high- and hill-country farms are no exception to this. On the surface, costs may be

\footnotetext{
* A Perspective is a qualitative and balanced overview of a topic supported by relevant published literature
}

a major determining factor on the decisions regarding use of fertilisers and lime, but the underlying reasons for specific fertiliser and lime decisions may be far more complex given various economic, environmental and social pressures. This paper focuses specifically on factors that influence fertiliser and lime decisions made by South Island high- and hill-country farmers.

\section{Study design}

This exploratory study used an inductive approach recommended by Eisenhardt (Eisenhardt 1989; Eisenhardt et al. 2016) to identify influencing factors and thinking processes about the decisions farmers make regarding use of fertilisers and lime. Qualitative in-depth interviews were conducted with 27 farmers from 24 high- and hill-country farms, from January 2019 to January 2020, to query the actual decisions made and the reasoning behind fertiliser and lime use in the preceding three years. Interviews were conducted face-to-face on farms, often at the kitchen tables. For some farms, conversations continued with a drive around the farm. Themes were then identified from the interview transcripts to form the basis for research results, conclusions and future recommendations.

Given the importance of the wider socio-economic environment to this study, it is prudent to recognise that all of the interviews were conducted before the worldwide COVID-19 pandemic took place in early 2020 (World Health Organisation 2020). Farming activities were going about as usual, with all of the competing interests within the New Zealand society mentioned above at play. Therefore, the results of this research reflect the thoughts of these farmers in a preCOVID-19 socio-economic environment, which may have changed dramatically thereafter.

It is also worth noting that the snowballing technique used in contacting farmers, where we sought recommendation of other farmer contacts from already interviewed farmers, has meant that our informants were not randomly selected. Rather, they were conveniently selected, and there is a likelihood that these farmers were more willing to communicate to other farmers and researchers compared to an 'average' farmer. Caution, therefore, should be taken in viewing our research results as representative of all South Island high- and hill-country farmers. What we present here, 
nevertheless, represent some of the thinking of some of these farmers.

\section{Research results \\ Generic Farm Descriptions}

The focus of this study was not on the farm system itself so we did not systematically collect data on farm operations. Therefore, only summary information is provided here to assist the understanding of the context for this research. The farms that we interviewed spanned from the Mackenzie District in Canterbury in the north to Central Otago and Queenstown Lakes Districts in Otago in the South (to protect privacy, only districts visited are shown in Figure 1 below). Several interviews were also planned for the Marlborough region which unfortunately had to be cancelled due to the country-wide lockdown in combat with the COVID-19 pandemic.

The high- and hill-country farms that we visited ranged from 1,400 ha to 28,000 ha in size. Seven out of the 24 farms are over 10,000 ha, and 10 are under 5,000 ha. Almost all of the farms have some land under irrigation. The proportion of irrigated land to total farm area varied widely. These irrigated paddocks play a vital role within the farm systems in producing feed supplements and finishing livestock. The intensity of the farming operation also ranged from all extensive, breeding only, to intensive breeding and finishing systems. To an extent, farmers' fertiliser and lime

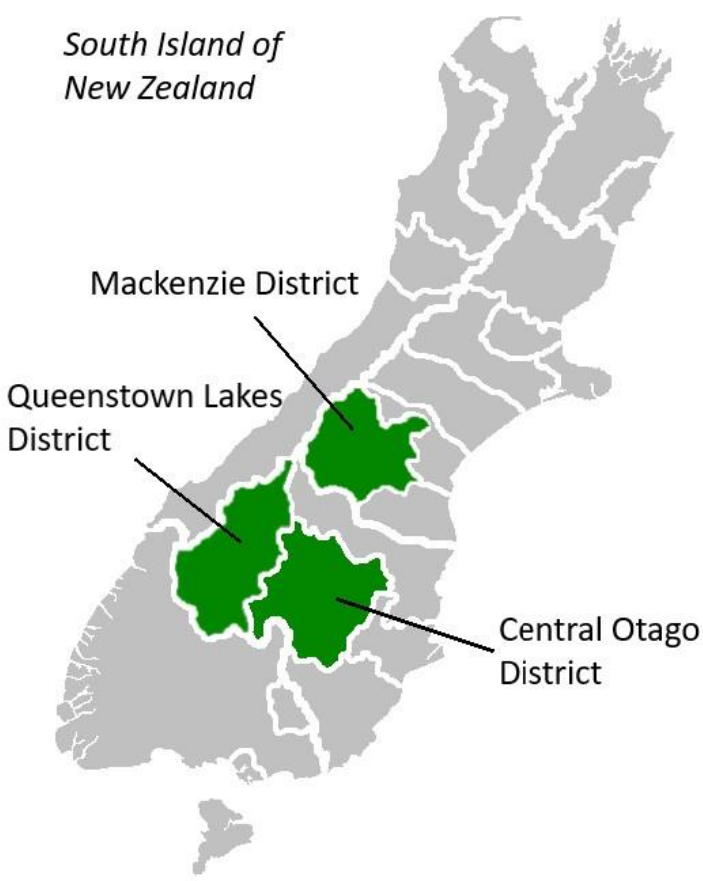

Figure 1 Districts of the South Island visited (highlighted in green) (Source: adapted from Creative Commons) decisions were determined by their farming intensity. For example, one farmer from an extensive highcountry station explained, "The number of stock units dictate the fertiliser requirement to a degree, because if livestock numbers increase, then the risk of the business also increases. This farm is predominantly a breeding country, not finishing country. It will be too risky to put too much fertiliser on then put on too much stock, partly due to the large scale of the place."

"We look at... how much we spend per stock unit. That's the guts of it", as one farmer explained. The average cost of fertiliser and lime (material and application) of these farms sits between $\$ 9$ and $\$ 16$ per SU wintered on-farm for the season prior to the interview. This amount is consistent with the data obtained from Beef + Lamb New Zealand farm surveys of South Island high- and hill-country farms, where the average combined total of fertiliser and lime cost was $\$ 12.99$ and $\$ 14.88$ per SU for 2017-18 and 2018-19 seasons respectively for high country, and $\$ 13.00$ and $\$ 15.15$ per SU for 2017-18 and 2018-19 seasons respectively for hill country (Beef + Lamb New Zealand 2020a, b).

\section{Many-faceted Challenges}

"[Soil] fertility was the number-one issue in farming", a retired high-country farmer pointed out. The success of a hill-country farm depends in part on their ability to effectively manage soil fertility to grow pasture and fodder crops used to adequately feed livestock. However, soil acidity and the associated aluminium toxicity pose a major challenge (Scrimgeour 2016). Ideally the determining factors for fertiliser and lime use are related mostly to soil type, $\mathrm{pH}$ level and crop nutrient requirements (Moir \& Moot 2010; Morton \& Roberts 2012). But, in reality, do farmers make these decisions purely based on science communication (Burns et al. 2003)? While it's about "getting the biggest bang for the buck with fertiliser [and lime]", we found that many other factors also influence farmers' decisions as to what fertilisers and lime to apply and when. The complex socio-economic environment at the time of this research, where both ecological and social uncertainties existed, suggests a lens of 'adaptive management' for our investigation (Jacobson et al. 2009). Not only does each farm possess a unique combination of biophysical conditions for production, each decision maker, the farmer, also has their own management style influenced by complex factors (Fairweather \& Keating 1994). Consequently, we recognise that every farm system is unique. Nevertheless, a number of common themes did emerge from our interviews with these selected South Island high- and hill-country farmers. We will describe these themes in the following sections. We recognise that some of the themes may seem nothing 
new to the readers. They are presented here, however, as these themes collectively portray the many-faceted challenges that South Island high- and hill-country farmers face when it comes to their fertiliser and lime decisions.

\section{Farm and paddock location}

Given the latitude span of the South Island, farm location was one of the key factors that influence fertiliser and lime decisions. Farm location largely determines the dominant climate and soil types on a farm, which in turn influence pasture growth rates, potential annual dry matter production, legume content and the efficacy of fertilisers and lime use (Haynes \& Williams 1993). Not all farms that we visited suffer from soil acidity problems, but, for those that do, lime application is a priority within the farm budget, knowing that aluminium toxicity would otherwise adversely impact on the growth of most legume species. A target of $\mathrm{pH}$ at 5.8 and above was indicated by a number of farmers interviewed.

Farm locations also determine the nearest fertiliser and lime depots, which in turn impact on the cost of transport of these farm inputs. For some farmers, the cost of transporting lime can be three or four times higher than the actual purchasing cost, making the total expense (cost plus transport and application) prohibitive in some years.

The location of a paddock or 'block', should it require any fertiliser or lime application, is also an important factor to consider for the farmers. Paddock location can mean, within a farm system, possible access to irrigation, steepness and aspect, impacting on sunshine hours, evapotranspiration rates, as well as soil temperature - all of which impact on plant growth. Paddock location also determines the distance to a main road or nearest airstrip for fertiliser and lime delivery and/or application for farmers, and therefore cost. There is more to it, however, than just logistics and costs when it comes to paddock location, as we explain further below.

\section{Soil test results}

All of the farmers that we interviewed conduct annual soil tests on selected paddocks. Two went further and soil-tested every paddock every year. Depending on the farm management system adopted, these tested paddocks can be fixed or randomly chosen by the farmer. Some farmers adopt a rotational regime with their soil testing; for example, a third of the farm per year, to ensure that every paddock on the farm gets soil tested every three years. These soil-test results inform farmers' fertiliser and lime decisions, which are often made in consultation with their fertiliser representatives.

"Fertiliser in the right place, at the right rate, is the best value for money that we are ever going to get. That doesn't mean fertiliser anywhere and everywhere. Far from it... [It should be] in line with soil tests", as one farmer explained. But soil-test results have to be used in conjunction with the role that the paddock plays within the farm system, as one farmer explained, "It's so complex... it's not just say, 'Well, the soil test says $x, y, z$. To fix that, I need to do this. It's so much more complicated, because you've got say, 'What's the role of this block, and how does it fit into my system, and I could justify it, if I could get this much grazing out of it, or it plays an important part of the whole system.".

Most farmers that we interviewed did not separate nitrogen fertiliser from other fertilisers in their comments, which may reflect the minimal use of nitrogen fertiliser on these extensively operated farms. One farmer mentioned that nitrogen fertiliser is a discretionary item that depends on the farm budget. The required nitrogen for pasture growth appear to be largely dependent on legumes, which is explained in the next theme.

\section{Legume survivability and abundance}

Of all the farms that we visited, legumes, particularly lucerne (Medicago sativa), play a very important part within the farm systems. For more than half of the farms visited, lucerne provided the crucial feed for finishing livestock on farm, which would otherwise be impossible to achieve. These lucerne paddocks are generally under irrigation, in developed paddocks on the flats. Priority for fertiliser and lime application is often given to these lucerne paddocks to ensure production. Many farmers also plant other legume species in their pasture mix, including a range of clovers (predominantly Trifolium spp.), perennial lupins (Lupinus polyphyllus) and lotus (Lotus pedunculatus). Choice of legume species to sow was not explicitly explained by farmers, although soil and climatic conditions along with historic practices on farms appear to have a major influence. Given the importance that legumes play in fixing nitrogen to improve soil fertility on non-irrigated paddocks in particular, the nutrient requirements of the chosen legume species often drive the decisions around fertiliser and lime on these paddocks. As one farmer explained about management decisions regarding legumes, "When it comes to permanent pasture, it's all about having a good legume. We used to think, jolly plant scientists, they've just got to grow something that fits our management. Now we think, jolly farmers have got to change their management to suit the plants."

\section{Public perception}

"Things have changed in the last few years. Public perception is now number one. Whether it's right or not ... That is our biggest hurdle, our biggest criteria, so 
that has to be in the forefront of your mind. Whatever you are going to do, make sure that you deal with that one first... Seeing is still believing, isn't it?" commented one farmer.

Closely intertwined with paddock location is the public perception that farm activities create. A number of farmers revealed to us that whether or not a paddock can be seen from a public road is a major factor to be taken into consideration when it comes to any farming activities planned for the paddock. It was common to hear during our visits, for example, that a paddock away from the public eye has been developed intensively for fodder crops. The farmer involved often confirmed to us that such development was undertaken in the paddock because it cannot be seen from a public road. One farmer in the Mackenzie District explained the impact of expected dryland vista by the public, "I think if it's highly visible country, anywhere down here in the viewing corridor down xxx Road, you would struggle. ... because from the other side of the basin, you look straight at it. That whole flat just climbs like that... the roads are 580 metres [above sea level] there, and we are 700 metres here, so people can see it from the other side... If there are green circles, or anything green, they would complain, and they do complain."

Farmers disagree with the basis on which some public and government agencies form their perception of how the landscape should look. One farmer in the Queenstown Lakes District indicated, "We keep having these arguments about these tussock flats. We are not allowed to cultivate the strip down beside the main road, for landscape, because DOC (Department of Conservation) considers it lovely and pristine, and what it used to look like. It's not. It's been modified over 150 years of farming."

The underlying connection drawn by these farmers is that land-use intensification is closely associated with increased fertiliser and lime use. Given this, these concerns of what the public would think directly impact on the fertiliser and lime decisions made by farmers, particularly for paddocks that are visible from main public roads.

\section{Changing climate}

"Climate change is happening", as one of the farmers simply put it. Indeed, many of our interviewees commented on the changes in climate that have occurred over the last few decades. One farmer in the Mackenzie basin spoke about having more than 20 extra frostfree days per year and more extreme weather events in recent years compared to a couple of decades ago.

This observed changing climate has been attributed as a possible reason for the increased prevalence of plant pests such as wilding pines by some farmers. One farmer commented, "Something is setting the wildings off. ... Something in the last 15 to 20 years has allowed it. Maybe it's the warming of the climate. I think there is a bit of that." Farmers also see this worsened pest problem a result of the reduction of wether flocks in many high- and hill-country farms, as wethers tend to graze wilding pine seedlings and keep them under control. This exacerbated pest problem has, in some cases, indirectly impacted on farmers' fertiliser and lime decisions, as some discretionary spending went towards pest control instead of improving soil fertility.

\section{Regulatory concerns}

Unanimously, farmers talked about their concerns over the increasingly stringent regulatory environment for farming. One farmer from the Mackenzie District, who manages a farm under Crown Lease, commented, "We are bound by what LINZ as our landlord allows us to do, and now, we are just about being stopped in our tracks totally through Plan Change 13, and Plan Changes 15 and 18, which restrict us hugely, and draws lines all over our maps. It seems ridiculous to me... for us to do any work in that, we have to apply for a resource consent."

Looking into the future, more concerns were raised, much of which is related to farm profitability and, therefore, how much can be put back on the farm to improve fertility:

"How much of our bottom line is going to be eroded because of emission taxes, water taxes... all these taxes in 10 or 20 years'time?"

"Everyone is under pressure at the moment... We are going to have to pay carbon tax in five years 'time. Where is that going to come from? I can't see it consistently coming out of the lamb cheque, so something has got to go, isn't it? ... In the $80 \mathrm{~s} . .$. everyone cut fertiliser out. It took the province 10 years to recover... Everyone is pretty reluctant to do that [right now]."

Given that fertiliser and lime use is closely linked to land-use intensity, the recent regulations on this have caused some concerns for farmers. Specifically, some farmers are concerned about the implication of 'grandparenting N' on some of their more intensively farmed paddocks, and what limitation that might bring into their farm systems:

"Places like this, we are ... 20 or 30 years behind the development that's happened further down the country, so we are just catching up. Now... they are going with 'grandparent $N$ ', so we are being penalised for being 20 or 30 years in hill country cultivation."

"We were going to go out of dairy grazing this year. But we've ... taken the advice... and decided to hang in there, because of the environment issues, because if grandparenting comes in... we are disadvantaging ourselves getting out of it." 


\section{Sustainability}

Under this increasingly stringent regulatory environment, farmers are working their way through as to how their operations can sustainably continue into the future. While farmers recognise the forces of this regulatory environment, they also see the importance of productivity and economic viability, which are closely linked to how they use fertiliser:

"You can't fight the systems at the moment. You've got to farm within the parameters that you are allowed to farm in. ... I think the biggest issue is how you sustainably feed five, six and then seven billion people. Say they banned $N, P, K, S$ and irrigation, you would have billions of people starving in a decade, or not even a decade. It's a balance. Everyone wants to be clean and green. But we also want to be profitable. We also want to feed the world..."

"People talk about [being] sustainable... in my opinion, it means that it covers a lot of things. You've got to be environmentally sustainable, but you've also got to be economically sustainable, otherwise you won't be there. It's all very good to have an idealistic approach... but that will have to be funded out of that business."

This understanding of sustainability is not limited to balanced nutrient in- and out- flows from the biophysical sense. This interpretation used by farmers may be different from that of the non-farming community. Other aspects of sustainability, such as long-term economic viability, as farmers see it, also influences their fertiliser and lime decisions.

\section{Market perception and demand}

Farmers recognise that the sustainable future of farming has to be based on a desirable image by the consumers in the market place. This image, when translated back to practices on farm, directly relate to fertiliser and lime decisions:

"Whatever impact we are having [on the environment], we are going to be able to justify. ... [The] market will expect us [to be] much more explicit about how we manage our production.... I sense that if we don't get it right, the consumer... is going to... shift... For me, there will need to be some hard yards that we are going to have to go through, otherwise we won't be able to say 'This is what's happening. This is the product that you are eating, and it has got integrity."

"I don't know that being defensive is necessarily enough for us, not when it comes to the consumers... We need to tell the story. But we need to know what's happening ... within our landscape, and that needs to have an integrity, [so] that we can actually say 'here is the basis for what we are claiming, and you can be satisfied that the product that you are purchasing is what it says it is."
This recognition of the importance of consumer perception and demand for environmentally responsible farming influences the attitude that farmers have towards how they do things on farm, including their fertiliser and lime decisions.

\section{Conclusions and future implications}

These themes identified above portray a complex matrix of factors that influence high- and hill-country farmers' fertiliser and lime decisions. While it is important for farmers to consider the requirements of the biophysical processes in soils and plants, largely via the aid of soil testing, many other socio-economic factors also come into play. Public perception, the increasingly stringent regulatory environment, particularly environmental regulations, and market perception and demand all play a role in farmers' minds when it comes to decision making on fertiliser and lime. These decisions are also influenced by a changing climate and the challenges brought by it, along with the goal of a sustainable future both financially and environmentally. None of these factors can be considered in isolation, reflecting the complexity of farm systems and the socio-economic environment they sit within.

Specifically, three of the eight themes identified (farm and paddock location, soil test results, legume survivability and abundance) are related to the internal biophysical conditions of the farm system; while four themes (public perception, changing climate, regulatory concerns, and market perception and demand) are external influences to the farm system. The theme on sustainability can be seen as both internal (economic viability) and external (demand from non-farming communities on long-term environmental balances). Intensification, to a large extent, has been closely linked by farmers to higher use of fertilisers and lime. Intensification is also closely associated to increased profitability to these high- and hill-country farmers, but their fear of the external factors limits their responses to actions demanded by the internal factors. These decisions reflect an adaptive management approach (Jacobson et al. 2009), and indicates that science communication (Burns et al. 2003) is not the only source of information for farmers' decision making.

Indeed, there are many more factors within a farm system that would play a role in a farmer's mind (Fairweather 1999; Fairweather \& Hunt 2011), which may well indirectly influence his/her decisions on fertiliser and lime. What we have identified here, nevertheless, are those in the forefront of these highand hill-country farmers' mind during conversations involving their fertiliser and lime decisions.

Since the completion of our field work, the world's landscape has changed dramatically due to COVID-19 pandemic. As we head into a global economic recession, 
agriculture has once again become the backbone of New Zealand's economy (Savory 2020). We sensed a somewhat depressed outlook by farmers during our interviews as they raised many of their concerns. As we go forward, the importance of agricultural production in feeding the nation and its export earnings for New Zealand, when other industries such as tourism and hospitality are suffering immensely may, however, bring a positive outlook and hence confidence in farmers. This confidence may in turn influence farmers' decision making, including those about fertiliser and lime, but that is yet to be verified. A pre- and postCOVID-19 farmer attitude investigation will make an interesting and valuable future study.

Going into the future, South Island high- and hillcountry farmers still face many challenges ahead. Most of the factors that we have identified above are likely to remain, albeit with perhaps less intensity on factors such as public perception, as the country rerecognises the importance of farming to the nation. It would seem logical, however, to encourage more engagement between high- and hill-country farming (and farming in general) and the non-farming communities, through which empathy for each other can be developed and appreciated. Indeed, as we assess the factors that have been identified through our research, it seems that a greater understanding of 'what's on the other side of the fence' would help to alleviate challenges brought to both the high- and hill-country farming community and the non-farming community by a lack of understanding. If people on 'either side of the fence' currently form their argument based on the science that is communicated to them (in highly simplified terms, either pro-production or proecology), then perhaps communicating the science 'across the fence' could enlighten some understanding for both.

\section{ACKNOWLEDGEMENTS}

This research was funded by Lincoln University. We are very grateful for the generosity of time by the high- and hill-country farmers whom we interviewed. Collectively your insights have made this research an enlightening experience.

\section{REFERENCES}

Beef + Lamb New Zealand. 2019. Sheepmeat and beef exports in 2019-20 both forecast to break \$4 billion for the first time. Retrieved 29 May 2020 from: https://beeflambnz.com/news-views/sheepmeat-andbeef-exports-2019-20-both-forecast-break-4-billionfirst-time

Beef + Lamb New Zealand. 2020a. Sheep \& beef farm survey: Class 1 South Island high country - all regions.
Beef + Lamb New Zealand. 2020b. Sheep \& beef farm survey: New Zealand South Island - Class 2 hill country.

Burns TW, O'Connor DJ, Stocklmayer SM. 2003. Science communication: a contemporary definition. Public Understanding of Science 12: 183-202. https://doi.org/10.1177/09636625030122004

Eisenhardt KM. 1989. Building theories from case study research. Academy of Management Review 14: 532-550. https://doi.org/10.5465/amr.1989.4308385

Eisenhardt KM, Graebner ME, Sonenshein S. 2016. Grand challenges and inductive methods: Rigor without rigor mortis. The Academy of Management Journal 59(4): 1113-1123. https://doi.org/10.5465/ amj.2016.4004

Fairweather JR, Keating NC. 1994. Goals and management styles of New Zealand farmers. Agricultural Systems 44: 181-200. https://doi. org/10.1016/0308-521X(94)90160-H

Fairweather JR. 1999. Understanding how farmers choose between organic and conventional production: Results from New Zealand and policy implications. Agriculture and Human Values 16: 51-63. https://doi. org/10.1023/A:1007522819471

Fairweather JR, Hunt LM. 2011. Can farmers map their farm system? Causal mapping and the sustainability of sheep/beef farms in New Zealand. Agriculture and Human Values 28: 55-66. https://doi.org/10.1007/ s10460-009-9252-3

Haynes R, Williams P. 1993. Nutrient cycling and soil fertility in the grazed pasture ecosystem. Advances in Agronomy, pp. 119-199. Elsevier. https://doi. org/10.1016/S0065-2113(08)60794-4

Jacobson C, Hughey KFD, Allen WJ, Rixecker S, Carter RW. 2009. Toward more reflexive use of adaptive management. Society \& Natural Resources 22: 484495. https://doi.org/10.1080/08941920902762321

Ministry of Business Innovation and Employment. 2018. Emerging growth opportunities in New Zealand food \& beverage. Wellington, New Zealand. https:// www.mbie.govt.nz/dmsdocument/2209-emerginggrowth-opportunities-nz-food-beverage-pdf

Moir JL, Moot DJ. 2010. Soil pH, exchangeable aluminium and lucerne yield responses to lime in a South Island high country soil. Proceedings of the New Zealand Grassland Association 72: 191-196. https://doi.org/10.33584/jnzg.2010.72.2788

Moir JL, Moot DJ. 2014. Medium-term soil pH and exchangeable aluminium response to liming at three high country locations. Proceedings of the New Zealand Grassland Association 76: 41-46. https:// doi.org/10.33584/jnzg.2014.76.2963

Morton JD, Roberts AHC (Eds). 2012. Fertiliser use on New Zealand sheep and beeffarms: the principles and practice of soil fertility and fertiliser use on 
New Zealand sheep and beef farms Wellington: New Zealand Fertiliser Manufacturers' Research Association. http://www.fertiliser.org.nz/includes/ download.ashx?ID=153081

Savory L. 2020. 'Thank God for farmers' being the economy's backbone, says economist. [Stuff news website 4 April]. Retrieved 25 May 2020 from: https://www.stuff.co.nz/southland-times/ news/120769601/thank-god-for-farmers-being-theeconomys-backbone-says-economist
Scrimgeour F. 2016. Pathways ahead for New Zealand hill country farming. Journal of New Zealand Grasslands 78: 73-82. https://doi.org/10.33584/ jnzg.2016.78.522

World Health Organisation. 2020. Rolling updates on coronavirus disease (COVID-19). Retrieved 29 May 2020 from: https://www.who.int/emergencies/ diseases/novel-coronavirus-2019/events-as-theyhappen 